\title{
Variability and spatial distribution of hydrodynamic properties in soil with preserved Caatinga
}

\author{
Variabilidade e distribuição espacial de propriedades hidrodinâmicas em solo com Caatinga \\ preservada
}

José Martins de França Neto ${ }^{1}$ (D), Artur Paiva Coutinho ${ }^{1}$ (D), Simone Di Prima ${ }^{2}$ (D), Saulo de Tarso Marques Bezerra ${ }^{1}$ (D), Severino Martins dos Santos Neto ${ }^{3}$ (D), Ana Emília Carvalho de Gusmão da Cunha Rabelo ${ }^{3}$, Aline Lima de Oliveira ${ }^{3}$ (D) \& Antonio Celso Dantas Antonino 3 (D)

\author{
${ }^{1}$ Universidade Federal de Pernambuco, Caruaru, PE, Brasil \\ ${ }^{2}$ University of Sassari, Sassari, Italy \\ ${ }^{3}$ Universidade Federal de Pernambuco, Recife, PE, Brasil
}

E-mails: jmfrancaneto@gmail.com (JMFN), arthur.coutinho@ufpe.br (APC), sdiprima@uniss.it (SDP), s.bezerra@yahoo.com.br (STMB), martinsdsn@gmail.com (SMSN), anarabelo@gmail.com (AECGCR), alinelimadeoliveira.alo@gmail.com (ALO), antonio.antonino@ufpe.br (ACDA)

\begin{abstract}
The functions of soil water retention and hydraulic conductivity are indispensable for the characterization and modeling of the infiltration and water transfer processes in the vadose zone. In the case of the Brazilian semi-arid region, characterized by the scarcity of water resources, there is a lack of information on the hydrodynamic properties of the soil. Also, these properties have numerous factors of variability, requiring the characterization of their magnitude and distribution in space. This research presents an analysis of the infiltration process and the hydrodynamic properties of the soil under native Caatinga forest, observing its spatial distribution. This vegetation is typical of the Brazilian semi-arid region. One developed a 48-point grid in an area of approximately $875 \mathrm{~m}^{2}$, and applied on it the Beerkan methodology. The analyzes were performed based on the application of the BEST-Slope algorithm and statistical measures of the position, dispersion, and adherence tests. The results showed medium to high variability indices for the hydrodynamic properties, with random spatial distribution, despite the verification of a homogeneous texture in the area. Thus, it was found that the soil structure was predominant in the processes of water infiltration.
\end{abstract}

Keywords: Vadose zone; Beerkan; Soil water retention curve; Hydraulic conductivity; Semi-arid.

\section{RESUMO}

As funções de retenção de água no solo e condutividade hidráulica são indispensáveis para a caracterização e modelagem dos processos de infiltração e transferência de água na zona vadosa. No caso do semi-árido brasileiro, caracterizado pela escassez de recursos hídricos, faltam informações sobre as propriedades hidrodinâmicas do solo. Além disso, essas propriedades possuem inúmeros fatores de variabilidade, sendo essencial a caracterização de sua magnitude, bem como sua distribuição no espaço. Esta pesquisa apresenta uma análise das propriedades hidrodinâmicas de um solo sob mata nativa da Caatinga, típica do semi-árido brasileiro, observando sua distribuição espacial. Uma malha de 48 pontos foi desenvolvida em uma área de aproximadamente $875 \mathrm{~m}^{2}$, onde foi aplicada a metodologia Beerkan. As análises foram realizadas com base na aplicação do algoritmo BEST-Slope e em medidas estatísticas de posição, dispersão e aderência. Os resultados mostraram índices de variabilidade médios a altos para as propriedades hidrodinâmicas, com distribuição espacial aleatória, apesar da verificação de uma textura homogênea na área. Assim, verificou-se que a estrutura do solo foi preponderante nos processos de infiltração de água.

Palavras-chave: Zona vadosa; Beerkan; Curva de retenção; Curva de condutividade hidráulica; Semiárido. 


\section{INTRODUCTION}

The analyses of the hydrodynamic properties of the soil are essential to the conception of water management models, especially in regions with a historical water shortage (Coutinho et al., 2016; Abaker et al., 2018; Bouslihim et al., 2019). In this context are included semiarid regions, that have shallow soils (Santos et al., 2012b; Paula Filho et al., 2019), low and irregular annual rainfall (Cirilo, 2008; Souza et al., 2016), and high evapotranspiration rates (Jha \& Srivastava, 2018; Mutti et al., 2019), resulting in constant drought periods (Han et al., 2018; Habibi et al., 2018) and the susceptibility to desertification (Joseph et al., 2018; Barros et al., 2018).

Therefore, a good understanding of these processes is vital to develop practical solutions to minimize socioeconomic and environmental issues. Besides that, the success of agricultural or engineering projects often depends on the determination of the soil's hydrodynamic properties, especially the hydraulic conductivity and water retention functions (Kool et al., 2019; Yost et al., 2019; Zubelzu et al., 2019). The hydraulic conductivity function provides the relationship between hydraulic conductivity and soil water content. In a qualitative way it expresses the propensity of the porous medium to transfer water to a given soil moisture. The soil water retention function describes the relationship between the soil water content and the matrix energy state. These properties are crucial for modeling the movement of water into the soil (Nasta et al., 2013).

Tests to determine soil's hydrodynamic properties can be performed in the field or laboratory by applying direct and indirect methods. Laboratory determinations are generally onerous and long time-consuming, hampering the spatial analyses on a significant scale (Souza et al., 2008a). Field methods, such as the Beerkan method (Lassabatère et al., 2006), allow the maintenance of the functional connections of the sampled volumes with the surrounding matrix (Haverkamp et al., 1994; Yilmaz et al., 2010; Bagarello et al., 2014; Alagna et al., 2016; Castellini et al., 2018; Fernández-Gálvez et al., 2019). Beerkan's method allows the determination of soil's hydrodynamic properties through simplified infiltration tests, particle size distribution, specific mass of the soil, and initial soil water content (Angulo-Jaramillo et al., 2019).

The hydrodynamic properties have various spatial variability sources (Šípek et al., 2019; Siqueira et al., 2019; Bagarello et al., 2019). The variability sources might be linked with soil's textural and structural characteristics. Therefore, determinations and studies of the soil's hydrodynamic properties on the field should follow a plan that contemplates their spatial distribution. According to Picciafuoco et al. (2019), not considering the spatial variability when using hydrologic models can lead to significant mistakes.

Criteria that qualify the variability indices according to their coefficient of variation are commonly used to characterize these indices and their distribution in space. An example is the Warrick \& Nielsen (1980) criteria, used in several studies, such as those by Cheong et al. (2020), Keskinen et al. (2019) and Moradi et al. (2016). Also, it is common to spatialize these parameters through geostatistical analyzes, with the help of GIS environments, as performed by Souza et al. (2017), Oliveira Júnior et al. (2014), and Souza et al. (2008a).
Although being crucial in the elaboration of water resources management models, information about the soil's hydrodynamic properties and their spatial distribution are scarce in semiarid regions. According to Albuquerque et al. (2012), in the Brazilian semiarid, where the Caatinga biome is predominant, the availability of data is even more limited. The few investigations conducted in these regions emphasize that the hydrodynamic parameters show indexes of variability between medium and high, according to the criteria of Warrick \& Nielsen (1980), being strongly correlated to the soil's texture (Souza et al., 2008; Santos et al., 2012a). Oliveira Júnior et al. (2014) also attributed the spatial distribution of hydrodynamic properties to the soil's texture in a preserved Caatinga area.

Despite the relation of the hydrodynamics spatial variability with the soil's texture, some investigations emphasize that there is still a lack of clarity on this relation. For example, Rahmati et al. (2018), assessing hydrodynamic parameters of the soil, verified a considerable variability among them for the same texture class. Godoy et al. (2019), when determining the spatial correlation between hydrodynamics parameters and soil properties, found out that the relationship them is not constant in space. This fact highlights the importance of determining the combined behavior of these variables. Consequently, there is a need to expand the investigations about the spatial distribution of the hydrodynamic properties to understand how these indexes vary with the soil's physical properties. Thus, this paper aims to characterize the spatial variability of the hydrodynamic properties using the Beerkan method in the soil of native Caatinga forest in the Brazilian semiarid region.

\section{MATERIAL AND METHODS}

\section{Study area}

The present research was developed in an experimental area located in the city of Caruaru, in the Agreste of the state of Pernambuco, Brazil's northeast (Figure 1). The area selected for the tests embraces an area of $875 \mathrm{~m}^{2}$ with a predominant vegetation of native Caatinga forest. The vegetation in the area is characterized by being thorny, deciduous, and varies from shrub to arboreal (Silva et al., 2017; Alcoforado-Filho et al., 2003).

According to Jacomine et al. (1973), the studied soil is a Planosol of medium depth, strongly drained, acid to moderately acid, and with medium natural fertility. According to the Köppen classification the region has a climate of Bsh '(hot semiarid) type, characterized by low humidity and little annual rainfall (average between $200 \mathrm{~mm}$ and $500 \mathrm{~mm}$ ). The study covered a mesh of 48 points in the surface, equidistant $5 \times 5 \mathrm{~m}$.

\subsection{Beerkan's methodology}

Beerkan's methodology is mainly based on simplified infiltration tests. The experiments consisted of recording the time to infiltrate fixed volumes of water $(50 \mathrm{ml})$, inside a containment ring of $150 \mathrm{~mm}$ of diameter, which was inserted to a depth of 

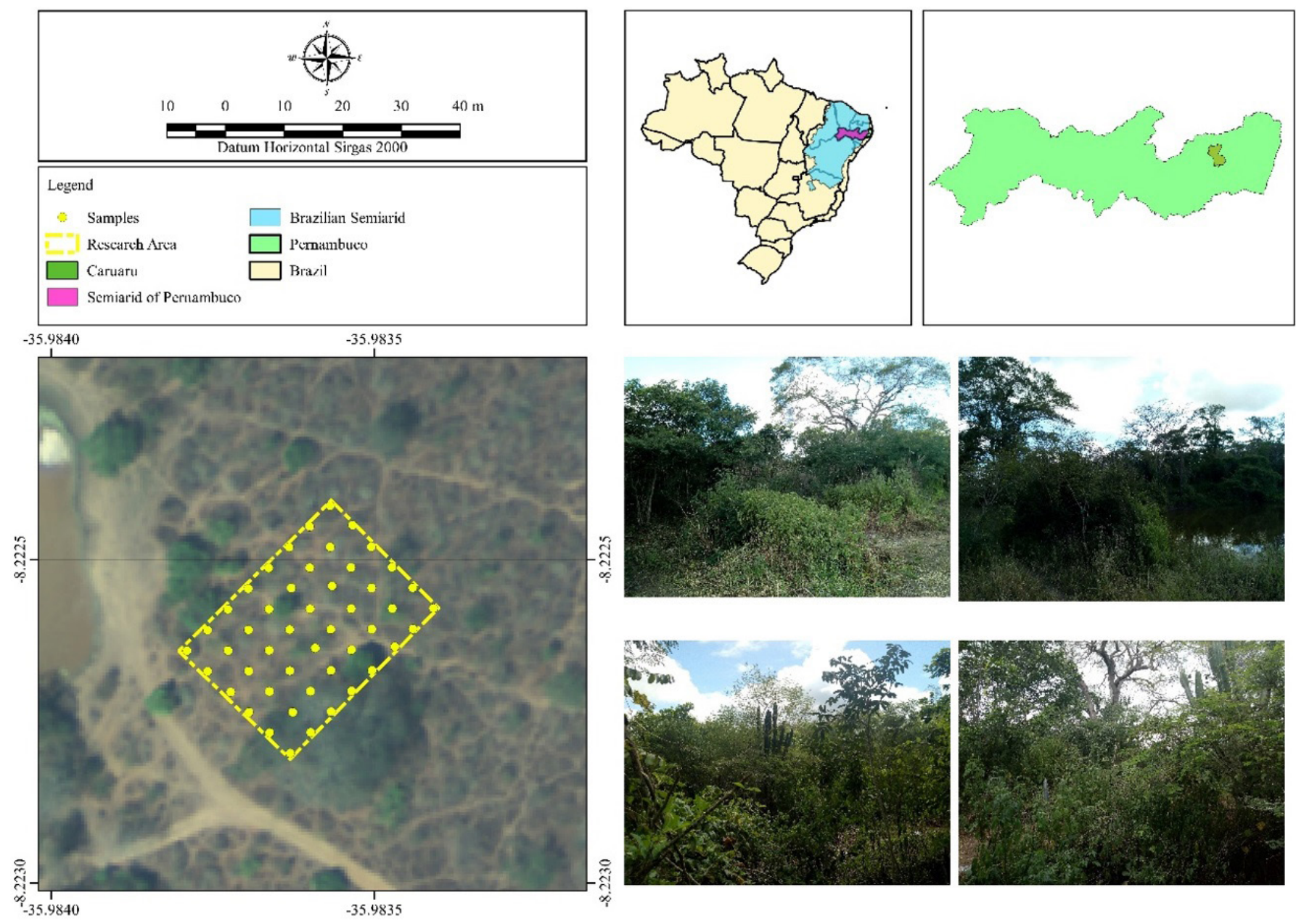

Figure 1. Images highlighting the regions where the study was made

about $10 \mathrm{~mm}$ into the soil. The volume of water was poured into the ring at time zero, and the time elapsed during the infiltration of a known volume of water was measured. When the first volume completely infiltrated, a second known volume of water was added to the ring, and the time needed for it to infiltrate was measured (time cumulative). According to Lassabatère et al. (2006), the procedure is commonly repeated for 8 to 15 known volumes. In this study, the procedure was fixed in 16 volumes for all experiments.

In each infiltration experiment, soil samples were collected to determine the initial soil water content $\left(\theta_{i}\right)$, particle-specific mass (@s), and particle size distribution (PSD). Another sample of known volume is extracted to determine the soil-specific mass (Q). At the end of the experiment, the saturated soil is sampled to determine saturated soil water content $\left(\theta_{s}\right)$.

Hydraulic properties are derived from the soil water retention curve proposed by van Genuchten (1980) and Burdine (1953) (Equation 1), and the soil hydraulic conductivity curve proposed by Brooks \& Corey (1964) (Equation 2).

$\left(\frac{\theta-\theta_{r}}{\theta_{S}-\theta_{r}}\right)=\left[1+\left(\frac{h}{h g}\right)^{n}\right]^{-m}$

with $m=1-\frac{2}{n}$
$K(\theta)=K s\left(\frac{\theta-\theta_{r}}{\theta_{s}-\theta_{r}}\right)^{\eta}$

with $\eta=\frac{2}{m n}+2+p$

where $\theta$ is the volumetric soil water content $\left[\mathrm{L}^{3} \cdot \mathrm{L}^{-3}\right] ; \theta_{s}$ is the saturated soil water content $\left[\mathrm{L}^{3} . \mathrm{L}^{-3}\right] ; \theta_{r}$ is the residual soil water content, assumed to be zero; $h$ is the soil water pressure head [L]; $h g$ is the inflection point of the water retention curve [L]; $n$ and $m$ are the shape parameters of the water retention curve, dimensionless $; K_{s}$ is the saturated soil hydraulic conductivity $\left[\mathrm{L}^{\mathrm{T}} \mathrm{T}^{-1}\right] ; \eta$ is the shape parameter of the hydraulic conductivity curve, dimensionless; and $p$ is a tortuosity parameter, dimensionless.

BEST (Beerkan Estimation of Soil Transfer Parameters through Infiltration Experiments) algorithm was used to calculate the parameters of shape $(m, n$, and $\eta)$ and normalization parameters $\left(K_{s}, S\right.$, and $\left.h g\right)$. There are three different BEST algorithms for estimating hydrodynamic parameters: BEST-Slope (Lassabatère et al., 2006), BEST-Intercept (Yilmaz et al., 2010), and BEST-Steady (Bagarello et al., 2014). BEST-Slope is the first algorithm developed by Lassabatère et al. (2006). BEST-Intercept is an adaptation developed for some specific cases of the infiltration curve, in which $K_{S}$ results in a negative value. BEST-Steady estimates the saturated hydraulic conductivity by fitting the infiltration curve 
at its stationary stage. Castellini et al. (2018) evaluating the three BEST methods, observed a better performance of the BESTSlope to describe the water retention curve. Aiello et al. (2014) highlights that BEST-Slope performed well for a study carried out on a soil with sandy loam texture. Therefore, the authors adopted BEST-Slope algorithm for this work.

The shape parameters $(m, n$, and $\eta)$ depend mainly on the soil texture, which are estimated from the particle size distribution (PSD). To obtain the shape parameters of the hydraulic curves, the PSD is fitted to the following equations:

$F(D)=\left[1+\left(\frac{D_{g}}{D}\right)^{N}\right]^{-M}$

with, $M=1-\frac{2}{N}$

where $F(D)$ is the cumulative frequency associated with diameter $D(\mathrm{~L}), M$ and $N$ are two shape parameters, and $D_{g}(\mathrm{~L})$ is a scale parameter.

The normalization parameters $\left(\theta_{s}, K_{s}\right.$ e $\left.h g\right)$ depend on the soil structure and are determined from the infiltration experiment. To estimate $K_{S}$ and $S$, BEST-Slope uses the experimental data obtained with the Beerkan method and infiltration model by Haverkamp et al. (1994). Particularly, BEST-Slope applies the first part of the cumulative infiltration curve to fit to the transient model and the final slope to describe the steady-state, determined by Equation 4 and 5 .

$K_{S}=i_{S}^{\exp }-A S^{2}$

$$
I(t)=S \sqrt{t}+\left[A(1-B) S^{2}+B i_{S}^{e x p}\right] t
$$

where $I$ is the cumulative infiltration $(\mathrm{L}) ; t$ is the time $(\mathrm{T}) ; i_{s}^{\exp }$ is the experimental steady-state infiltration rate $\left(\mathrm{L}^{\mathrm{T}} \mathrm{T}^{1}\right) ; A$ and $B$ are constants (Brooks \& Corey, 1964); $S$ is the Sorptivity (L.T T $^{-0,5}$ ).

\section{Characteristic scale soil properties}

During the three-dimensional infiltration process, the factors affecting the water flow into the soil are the geometry of the water source, soil capillarity, and gravity (Souza et al., 2008a, 2016; Oliveira Júnior et al., 2014). One of the ways to characterize these factors is from the capillary length scales, $\lambda c[L]$ (White \& Sully, 1987) and the characteristic radius of hydraulically active pores, $\lambda \mathrm{m}[\mathrm{L}]$ (Philip, 1987), which are determined by Equations 6 and 7, respectively.

$$
\lambda_{c}=\frac{b S^{2}}{\left(\theta_{s}-\theta_{i}\right) K_{s}}
$$

where $b$ is a constant dependent on soil water diffusivity, being considered $b=0.55$ (Bouarafa et al., 2019).

$$
\lambda_{m}=\frac{\sigma}{\rho_{w} g \lambda c}
$$

where $\sigma$ is the surface tension of water $\left(\sigma=73 \mathrm{mN} \cdot \mathrm{m}^{-1}\right) ; \varrho_{w}$ is the specific mass of water $\left(\varrho_{w}=1000 \mathrm{~kg} \cdot \mathrm{m}^{3}\right)$; and $g$ is the acceleration of gravity $\left(g=9.80 \mathrm{~m} \cdot \mathrm{s}^{-2}\right)$.
Also, the number of pores per unit area, $C \lambda_{m}\left(\mathrm{~N}^{\circ}\right.$ of pores. $\mathrm{m}^{-2}$ ) was determined using Poiseuille's law for flow into a capillary tube, according to Equation 6 (Souza et al., 2007, 2016).

$$
C \lambda_{m}=\frac{8 \mu K_{s}}{\rho_{w} g \pi \lambda_{m}{ }^{4}}
$$

where $\mu$ is the dynamic viscosity of water $\left(0.001 \mathrm{~kg} \cdot \mathrm{m}^{-1} \cdot \mathrm{s}^{-1}\right)$.

\section{Parameter analysis}

Initially, a statistical analysis of the parameters under study was performed, with the position measures, covering the determination of the arithmetic mean and median of the sample, also included the dispersion measures, such as standard deviation, variance, and coefficient of variation, in addition to a measure of asymmetry, with the determination of the asymmetry coefficient.

The determination of the variability indexes of the parameters was carried out based on the criteria introduced by Warrick \& Nielsen (1980), which relate the samples' degree of variability with their coefficient of variation. Variability is considered low if its variation coefficient is less than $12 \%$; medium if it is between 12 and $60 \%$; and high if the values are above $60 \%$.

To check the quality of the adjustment of the variables, the Kolmogorov-Smirnov test was applied to determine the adherence of the parameters to a normal distribution or log-normal distribution, considering 5 and $1 \%$ of significance, as also used in the studies of variability by Souza et al. $(2017,2008 \mathrm{a})$ and Oliveira Júnior et al. (2014). An uncertainty analysis was performed for the parameters $\eta, \theta_{S}, K_{S}$, and $S$. For these parameters, the respective confidence intervals were calculated, considering the normal or log-normal distributions at 5\% significance.

\section{Analysis of the spatial distribution of parameters}

To analyze the spatial distribution of the parameter indices and, thus, to verify their variability and possible spatial correlation, maps were plotted with the scores of all the analyzed parameters, using the Quantum Gis software, version 2.18.28. The maps were organized into 5 ranges of scores, with different colors, in which the blue strip indicates the highest indices, the red the lowest indices and the yellow the intermediate indices.

\section{RESULTS AND DISCUSSIONS}

\section{Texture classification, soil water infiltration curves, and statistical analysis of parameters}

The fractions of sand, silt, and clay, and the respective textural classifications of the 48 points were determined from the particle size analysis. According to United States Department of Agriculture (1987), the 48 studied points were classified as sandy loam (Figure 2a). Figure $2 \mathrm{~b}$ shows the infiltration curves for the 48 points. 
The infiltration tests lasted, on average $2030 \mathrm{~s}$, with the fastest test taking $848 \mathrm{~s}$ and the most extended taking $3630 \mathrm{~s}$. Infiltrations with a shorter duration (below average), observed in $54 \%$ of the points, may be related to a higher density of vegetation cover, which indicates the strong presence of roots inside the soil (Nunes et al., 2012). Therefore, it is easier for the water to infiltrate the soil due to the preferential flows formed by the roots.

Ma et al. (2016) evaluating soils of different textures in a semiarid region, found a correlation between the infiltration curves and the textural variation. In contrast, the 48 points analyzed in our study, presented same textural classification and a high discrepancy

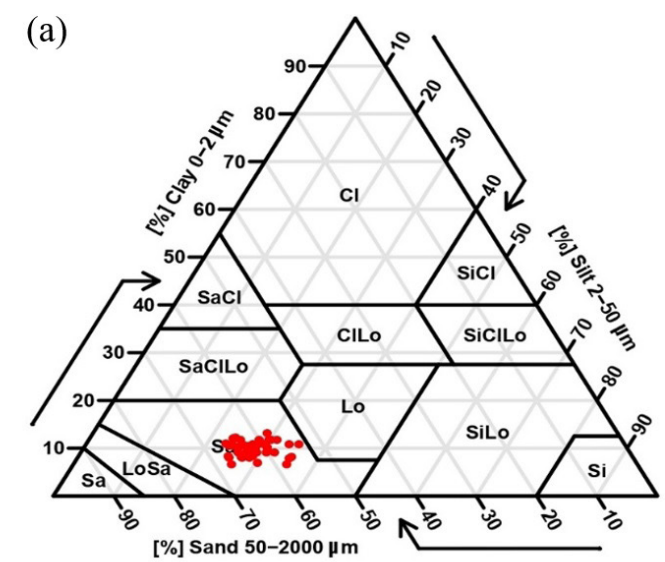

(b)

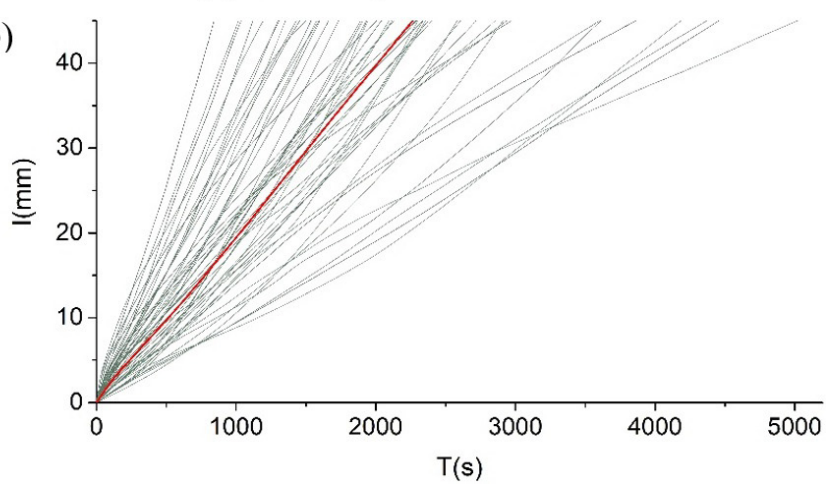

Figure 2. (a) The textural class of the 48 points studied; (b) Cumulative infiltration curves of the 48 points analyzed, with $\mathrm{I}(\mathrm{mm})$ being the accumulated infiltration layer of soil water, $\mathrm{T}$ (s) the duration to infiltrate all water volumes and the red line corresponding to the average infiltration curve. between infiltration curves (Figure 2a). This probably indicates an influence of the soil structure on the infiltration curves.

It is possible to verify the atypical behavior of some infiltration curves (concave, large double, or discontinuous), representing the presence of non-soil water repellent regions. According to Vogelmann et al. (2015), forest soils commonly present hydrophobic organic compounds. Clothier et al. (2000) and Moret-Fernández et al. (2019) indicate's that water repellency modifies soil water dynamics, reducing matric potential and affecting infiltration capacity. In this sense, when the repelling effect disappears, it is common to observe atypical, discontinuous, and double-slope infiltration curves, especially in very dry soil conditions (Vogelmann et al., 2017; Li et al., 2018).

Table 1 shows the statistical design for the soil physical properties and shape parameters of Beerkan's method. According to the Kolmogorov-Smirnov test, the sand, silt, clay, and particle density parameters were adjusted to a normal distribution at $5 \%$ significance, while the soil density was adjusted to $1 \%$ significance. The average values of sand, silt, and clay fractions are 61.91, 28.29, and $9.80 \%$, respectively.

The indicative of higher sand contents is pertinent to the Planosols superficial layers found in the semiarid region, as observed by Oliveira et al. (2009) and Sousa et al. (2013). According to Silva et al. (2012), that this occurs due to the loss of clay on the surface as a result of eluviation or dissolution.

Taking as indicators the limits of Coefficient of Variation (CV) established by Warrick \& Nielsen (1980), sand and silt fractions have low variability $(\mathrm{CV}<12 \%)$, and average variability in the clay fraction $(12 \%<\mathrm{CV}<62 \%)$. Chagas et al. (2016) evaluated the texture variation of the soil's superficial layer in the Brazilian semiarid using the criteria of Warrick \& Nielsen (1980). They verified an average variability for sand, silt and clay fractions. Araújo et al. (2018), in their studies on Yellow Argisols, Litossolos, and Neossolos, obtained low and/or medium variability in textural fractions in superficial layers of semiarid soils, according to the criteria of Warrick \& Nielsen (1980). All textural fractions exhibited distributions close to the symmetry, considering the index presented by the coefficient of skewness.

The average of the soil specific mass was $1.50 \mathrm{~g} \cdot \mathrm{cm}^{-3}$, a typical value for sandy soils, as specified by Reinert \& Reichert (2006) and Chatterjee et al. (2018). The results were also similar to those obtained by Vital et al. (2015) and Marinho et al. (2019), who evaluated the specific mass in Caatinga soils. A low variability

Table 1. Statistical analysis of soil physical indexes and Beerkan method shape parameters of the 48 studied points.

\begin{tabular}{|c|c|c|c|c|c|c|c|c|c|}
\hline \multirow{2}{*}{ Parameters } & Sand & Silt & Clay & \multirow{2}{*}{\multicolumn{2}{|c|}{$\begin{array}{c}\varrho \\
----[\text { g.cm }\end{array}$}} & \multirow{2}{*}{$\begin{array}{c}\sigma \\
{[\%]}\end{array}$} & n & $\eta$ & $\mathrm{m}$ \\
\hline & \multicolumn{3}{|c|}{ 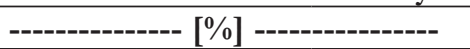 } & & & & \multicolumn{3}{|c|}{------------- [-] ----------- } \\
\hline Mean & 61.91 & 28.29 & 9.80 & 1.50 & 2.43 & 38.15 & 2.24 & 11.01 & 0.11 \\
\hline Median & 62.59 & 28.25 & 9.54 & 1.56 & 2.43 & 35.55 & 2.24 & 11.09 & 0.11 \\
\hline St.Dev & 3.12 & 3.20 & 1.56 & 0.16 & 0.06 & 6.93 & 0.01 & 0.50 & 0.00 \\
\hline Variance & 9.76 & 10.23 & 2.42 & 0.03 & $10^{-3}$ & 48.04 & $10^{-3}$ & 0.25 & $10^{-3}$ \\
\hline CV $[\%]$ & 5.05 & 11.30 & 15.89 & 10.83 & 2.57 & 18.17 & 0.65 & 4.55 & 5.44 \\
\hline Asymmetry & -0.51 & 0.58 & -0.12 & -0.72 & 0.24 & 0.60 & -0.01 & 0.32 & 0.05 \\
\hline Maximum & 67.26 & 35.35 & 13.06 & 1.80 & 2.56 & 52.06 & 2.27 & 12.34 & 0.12 \\
\hline Minimum & 53.96 & 22.98 & 6.59 & 1.13 & 2.31 & 25.62 & 2.21 & 10.17 & 0.09 \\
\hline$\varrho$-value KS & $0.48^{* *}$ & $0.66 * *$ & $0.79 * *$ & $0.04^{*}$ & $0.55^{* *}$ & $0.08^{* *}$ & $0.99 * *$ & $0.96 * *$ & $0.99 * *$ \\
\hline
\end{tabular}

Note - Studied indexes: $\varrho=$ soil specific mass; $\rho s=$ particles specific mass; $\sigma=$ porosity; $\mathrm{m}, \mathrm{n}$ and $\eta=$ shape parameters. Statistical Parameters: St.Dev $=$ statistic deviation; $\mathrm{CV}=$ coefficient of variation. ${ }^{*}$ normal distribution at $1 \%$ significance $(0.050>\varrho-$ value $>0.010)$; $* *$ normal distribution at $5 \%$ significance $(\varrho-$ value $>0.050)$. 
$(\mathrm{CV}<12 \%)$ was verified when considering the Warrick \& Nielsen (1980) limits for this index. These results are according to Melo et al. (2008) and Oliveira Júnior et al. (2014), who also found low-specific mass variability for native Caatinga forests.

The particle-specific mass average was $2.43 \mathrm{~g} \cdot \mathrm{cm}^{-3}$, particlespecific mass is related to the mineralogy and organic matter content, and usually does not vary widely. The small variability observed shows the relationship of this parameter with the soil texture, being barely influenced by the eventual variations in the organic matter content between the points.

The average porosity was $38.14 \%$ and the coefficient of variability was $18.17 \%$, indicating an average variability. Their distribution was close to the symmetry. It is expected that the forest soils present variations in their total porosity for the same textural class. This happens due to the competitiveness among the species, ground fauna, and its consequent compaction variations (Barreto et al., 2006; Rodrigues et al., 2016). Di Prima et al. (2016), in their studies, observed a total porosity with an average value of $55.1 \%$ for sandy loam soil. This average value is higher than those obtained in the present work, evidencing that this result is probably linked to the different land uses studied.

Regarding the shape parameters, the average values were 2.24 for the $n$ parameter, 0.11 for $m$ and 11.01 for $\eta$. According to the Warrick \& Nielsen (1980) criteria all these parameters have low variability $(\mathrm{CV}<12 \%)$ and a fairly symmetrical distribution, highlighting their relationship with the soil texture.

Minasny \& McBratney (2007), evaluated the variation of shape parameters between USDA textural classes. These authors found mean values of 2.27; 0.24 and 10.49 for $n, m$, and $\eta$, respectively, for sandy loam soils. Gomes et al. (2015) evaluated the hydrodynamics parameters of sandy soil, obtaining similar values to this study ( $n=2.50 ; m=0.17$ and $\eta=10.71)$. Lassabatère et al. (2006) and Santos et al. (2012a), who analyzed the $n, m$, and $\eta$ parameters for different textural classes, emphasize that the values of $n$ e $m$ are commonly higher in coarse soils like the sandy soils than in fine soils. The inverse was observed for $\eta$ in both works.

Table 2 shows the statistical analysis performed for the initial soil water content, the scale parameters, and the characteristic scales. The Kolmogorov-Smirnov test indicated an adjustment to a normal distribution at $5 \%$ significance, except for the $C_{\lambda \mathrm{m}}$, which did not show normality to the studied reliability indexes. The $K_{s}$, particularly, despite adjusting to the normal distribution, showed a better fit to the log-normal distribution with $5 \%$ significance.

The soil water content is an essential factor in the analysis of the water infiltration processes in the soil. In this study was obtained an average value of $\theta i$ of $0.06 \mathrm{~cm}^{3} . \mathrm{cm}^{-3}$ with high variability $(\mathrm{CV}>60 \%)$. Regarding the $\theta_{s}$, this study presented an average value of $0.39 \mathrm{~cm}^{3} \cdot \mathrm{cm}^{-3}$, a medium variation $(\mathrm{CV}=18.98 \%$ ), and a low asymmetry in its distribution $(>0.5)$. The average $\theta_{S}$ value obtained is close to that observed by Souza et al. $(2008,2016)$, which was $0.37 \mathrm{~cm}^{3} \cdot \mathrm{cm}^{-3}$ for sandy soils.

The average value of the saturated hydraulic conductivity $\left(K_{s}\right)$, was $0.02 \mathrm{~mm} \cdot \mathrm{s}^{-1}$, ranging between 0.005 and $0.046 \mathrm{~mm} . \mathrm{s}^{-1}$. Montenegro \& Montenegro (2006), evaluating $K_{S}$ of sandy loam soils, obtained average values of $0.083 \mathrm{~mm} . \mathrm{s}^{-1}$. Shwetha \& Varija (2015), analyzing the hydrodynamic parameters of sandy loam soil, recorded average $K_{S}$ values of $0.019 \mathrm{~mm} . \mathrm{s}^{-1}$, with minimum and maximum values of 0.016 and $0.022 \mathrm{~mm} . \mathrm{s}^{-1}$, respectively, which were similar to the ones registered in this work. Rahmati et al. (2018) registered for a loam sandy soil an average of $0.08 \mathrm{~mm} \cdot \mathrm{s}^{-1}$ for $K_{s}$. This parameter presented an average variability $(C V=50 \%)$ and a fairly symmetrical distribution. This behavior was also observed by Aiello et al. (2014), who obtained average values of $0.005 \mathrm{~mm} \cdot \mathrm{s}^{-1}$ for sandy loam soils and average variability.

According to Souza et al. (2016), the sorptivity reflects the soil capacity to absorb water by capillarity and depends on the soil structure and the variation of the soil water content between the beginning and end of the infiltration process. The $S$ average value was $0.253 \mathrm{~mm} \cdot \mathrm{s}^{-0.5}$, with minimum and maximum values of 0.105 and $0.571 \mathrm{~mm} . \mathrm{s}^{-0.5}$, respectively. According to the Warrick $\&$ Nielsen (1980) criteria its variation was also considered average $(\mathrm{CV}=37.55 \%)$. Alagna et al. (2016) estimated average values of 0.023 and $0.010 \mathrm{~mm} . \mathrm{s}^{-0.5}$ for sorptivity in sandy loam soil. Ursulino et al. (2019) obtained average values of $1.2 \mathrm{~mm} . \mathrm{s}^{-0.5}$ for sandy loam soils and Rahmati et al. (2018) for a loam sandy soil registered an average of $0.023 \mathrm{~mm} . \mathrm{s}^{-0.5}$.

The $h g$ parameter presented an average of $-3.795 \mathrm{~mm}$, with high variability, according to the Warrick \& Nielsen (1980) criteria. Lafayette et al. (2019) recorded $h g$ values of - 65 and $-80 \mathrm{~mm}$ for sandy loam soils, while Ursulino et al. (2019) verified average $h g$ values of $-167 \mathrm{~mm}$ for the superficial layer in sandy loam soil.

Table 2. Statistical analysis of the scale parameters of the Beerkan method and soil characteristics scales for the 48 studied points.

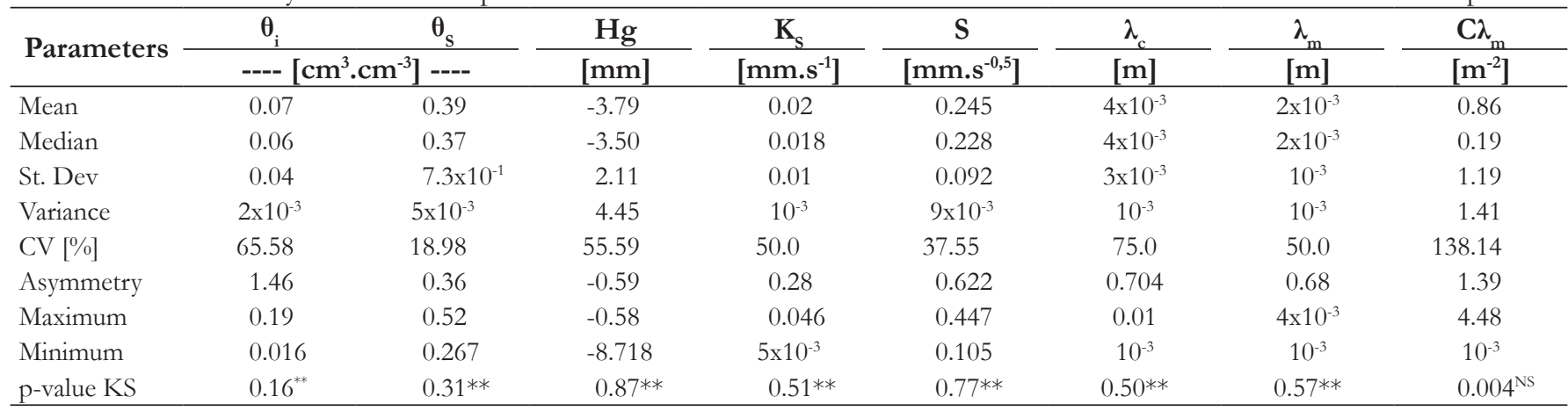

Note - Studied indices: $\theta \mathrm{i}=$ initial soil water content; $\theta \mathrm{s}=$ saturation soil water content; $K s=$ saturated hydraulic conductivity; $S=$ sorptivity; $h g=$ inflection point of the water retention curve; $\lambda c=$ capillary length scales; $\lambda=$ radius of hydraulically active pores; $C \lambda=$ number of pores per unit area; $C V=$ coefficient of variation. $* *$ normal distribution at $5 \%$ significance $(\varrho-$ value $>0.050)$. Ns no adjustment to the normal distribution. 
In general, it is possible to highlight that for the same textural class, there is a significant difference in the $K_{s}$ parameter, other authors observed the same behavior for $K_{s}$. The soil hydraulic properties, such as $K_{S}$ and $S$, depends on the texture, but are directly associated with others soil properties, especially with the structural arrangements (Souza et al., 2017). Oliveira Júnior et al. (2014) found a high variability of $K_{s}$ studying Caatinga native soils. Souza et al. (2008a) for the Fluvic Neossol also obtained medium variability for hydrodynamic parameters, while for the Yellow Latosol, the $K_{s}$ parameter showed high variability.

Finally, the average values obtained for $\lambda \mathrm{c}, \lambda \mathrm{m}$ and $C \lambda m$ were $7.4 \times 10^{-3} \mathrm{~m}, 2.4 \times 10^{-3} \mathrm{~m}$ and $660.75 \mathrm{No}$. of pores. $\mathrm{m}^{-2}$, respectively. High variability was observed for the three parameters, according to the adopted criteria. Souza et al. (2007), comparing the hydrodynamic parameters and characteristic scales for a surface without a crust and another with a crust with a sandy-clay texture, found average $\lambda \mathrm{m}$ and $C \lambda m$ values of $1.6 \times 10^{-3} \mathrm{~m}$ and $2.03 \times 10^{3}$ No. of pores. $\mathrm{m}^{-2}$, and $1.9 \times 10^{-3}$ and $0.54 \times 10^{4}$ No. of pores. $\mathrm{m}^{-2}$, respectively.

Figure 3 shows the QQ plot with a confidence interval for the normal distribution for the shape parameter $\eta$ and the scale parameters $\theta_{S}$ and $S$ and $\log$-normal distribution for $K_{S}$.

It is possible to verify a good adherence of the theoretical distributions to the empirical distributions of the hydrodynamic parameters at a significance level of $5 \%$. In the particular case of $K_{s}$, there was also good adherence to the normal distribution, also observed in the works by Oliveira Júnior et al. (2014) and Souza et al. (2017). However, the adjustment to the log-normal distribution showed greater precision, as also verified by Di Prima et al. (2016) and Bouarafa et al. (2019).

The parameters of these distributions allow the estimation of the main hydrodynamic properties associated with levels of probability of occurrence, making it possible to associate the levels of probability to the estimation of measures dependent on $\eta, \theta_{s}, K_{s}$, and $S$.

\section{Soil water retention curves and hydraulic conductivity curves}

The shape $(m, n$, and $\eta)$ and scale $\left(\theta \mathrm{s}, h g\right.$ and $\left.K_{s}\right)$ parameters values of the retention and hydraulic conductivity functions, enabled the delineation of the soil water retention curves $\theta(\mathrm{h})$ (Figure 4a) and soil hydraulic conductivity curves $K(\theta)$ (Figure 4b).

Accorindg Figure 3, the retention curves showed relative dispersion as the $\mathrm{h}$ value decreased. The dispersed behavior was also observed for the hydraulic conductivity curves. According to Pinheiro \& Teixeira (2009), despite the homogeneity of the texture, the variability presented by the retention curves and hydraulic conductivity may be associated with vegetation and its influence on soil structure and surface coverage. This is because (a)

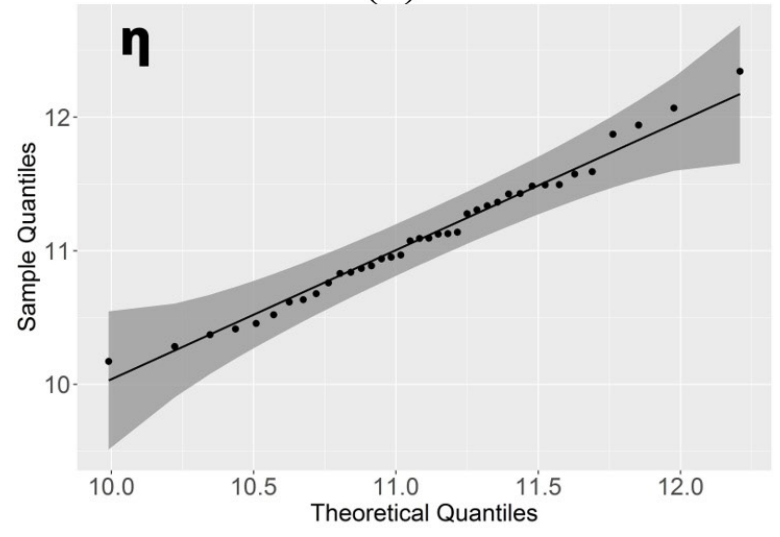

(c)

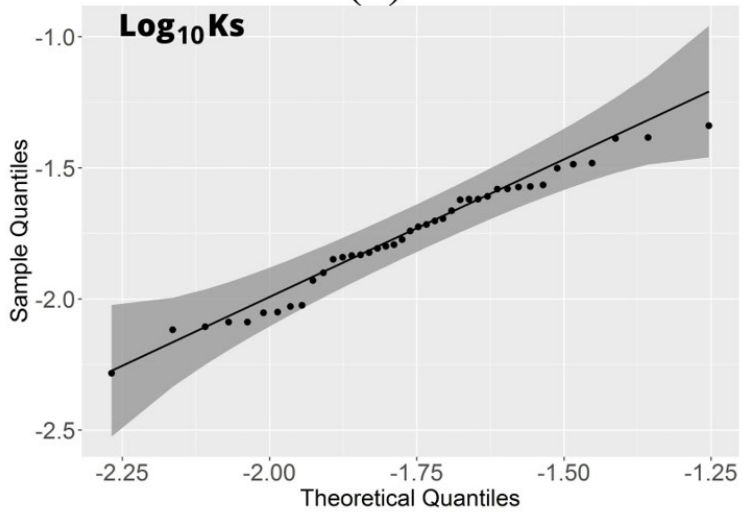

(b)

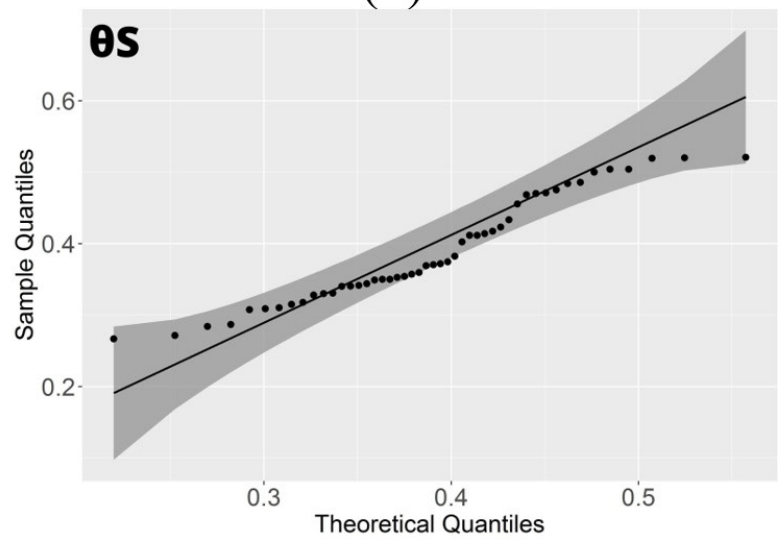

(d)

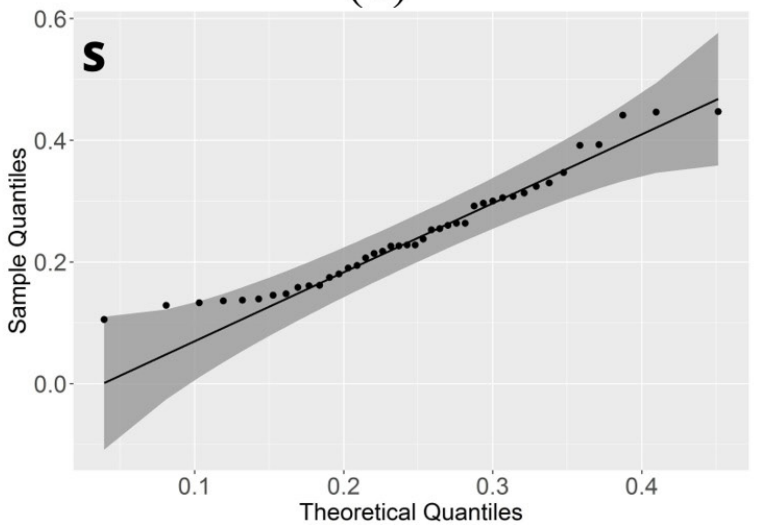

Figure 3. Graphics QQ Plot. (a) shape parameter $\eta$; (b) saturation soil water content, $\theta_{s}$; (c) hydraulic conductivity, $K_{s}$; (d) sorptivity, $S$. 

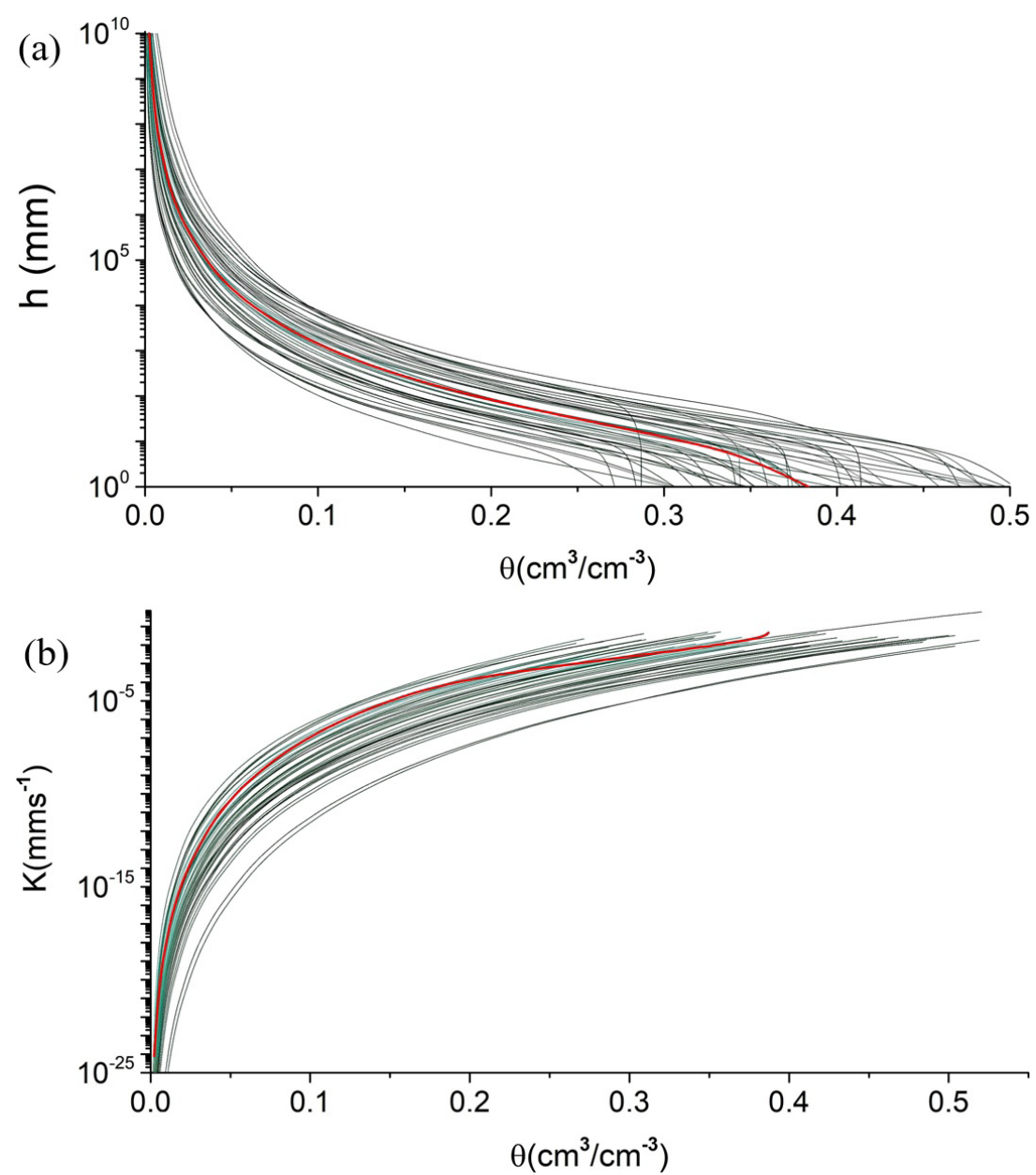

Figure 4. Soil water retention curves (a) and Hydraulic conductivity curves (b) of the 48 points, where h is the soil matrix potential, $\theta$ a soil water content, $\mathrm{K}$ the hydraulic conductivity and the red lines corresponding to the respective average curves.

numerous species compete with each other in the same area. These groups have different sizes, physiologies, and root thicknesses. Besides that, their arrangement in the soil can cause preferential or difficult paths for water conductivity.

\section{Graphical representation of the spatial distribution of the studied parameters}

Figure 5 shows the maps with the spatial distribution of the parameters analyzed in the study area. Due to the homogeneity of the texture between the points studied, there was no need for spatial visualization of the textural indexes. It is possible to observe that the parameter $\eta$ presented an inverse relation to $m, n$ and $\varrho$. The parameters $m$ and $n$ demonstrate a positive correlation with $\varrho$.

The maps of the $K_{s}, S$ and $h g$ parameters and the characteristic scales are random in their spatial distribution. Although they depend on the structure and texture of the soil, there was no high correlation between these parameters and the physical indexes of the soil or with the shape parameters presented.

Some hypothesis for the lack of visualization on a direct correlation, in soil covered by forest, are plant growth / death events, species competition and the action of microorganisms, which are random and do not follow a homogeneous distribution.
Therefore, these aspects interfere in the soil structure, promoting a random spatial distribution between the parameters.

Godoy et al. (2019) found a strong positive correlation between hydraulic conductivity and effective porosity. Despite this, they found that the correlation between the transport and physical properties of the soil is not constant. Then, for better identification they pointed out the need for depth studies on the soil structure on a microscale. Souza et al. (2017), analyzing soils of the semiarid region, did not verify a significant relation of $K_{s}$ with the soil's physical properties. However, they found an inverse relationship of the $K_{S}$ with the sorptivity, the specific mass and macroporosity.

Regarding the characteristic scales, it is possible to highlight a significant inverse relationship between the parameters $\lambda c$, and $h g$, while $\lambda \mathrm{m}$ showed a direct relationship with hg. The sorptivity, however, showed a direct correlation with the scale parameters. The other parameters showed no significant correlations with scale parameters. But, Gharedaghloo et al. (2018) found a decrease in hydraulic conductivity attributed to reduced pore radius and an increased pore tortuosity. The difficulty in adequately incorporating the macropore network in small volumes of soil samples may justify the unrelated relationship between pore scales and $K_{s}$, as highlighted by Di Prima et al. (2018). 
(a)

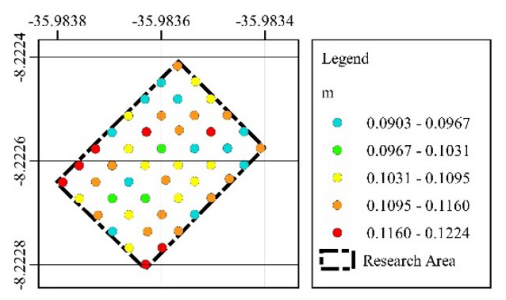

(c)

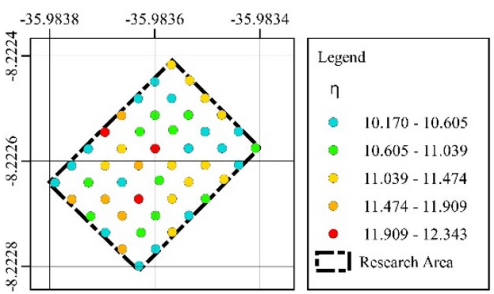

(e)

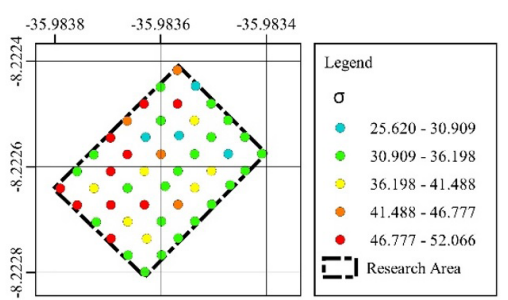

(g)

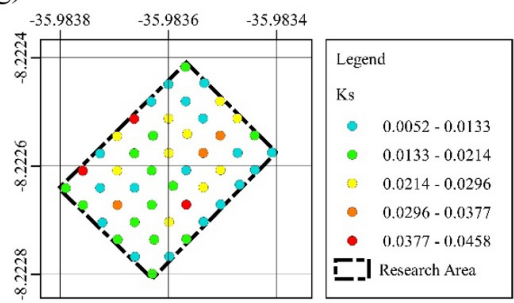

(i)

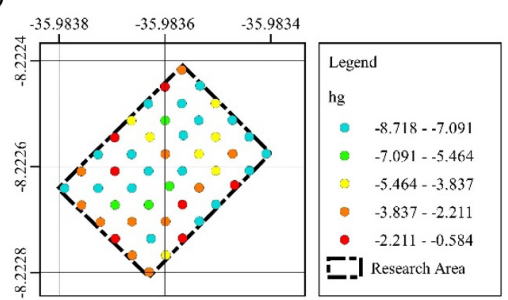

(k)

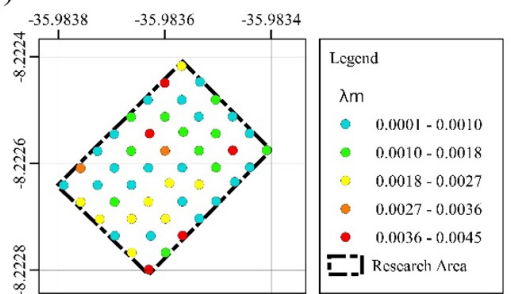

(b)

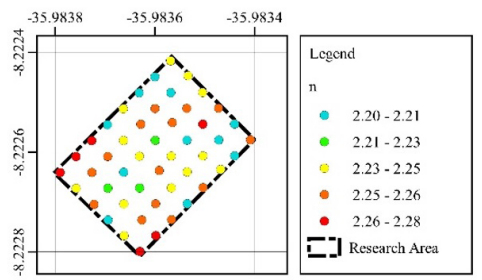

(d)

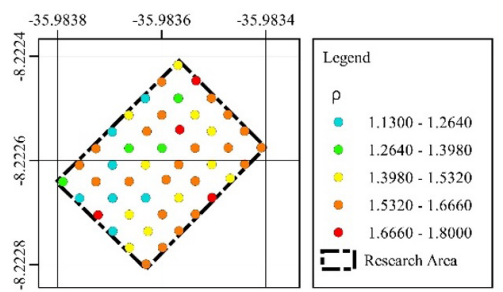

(f)

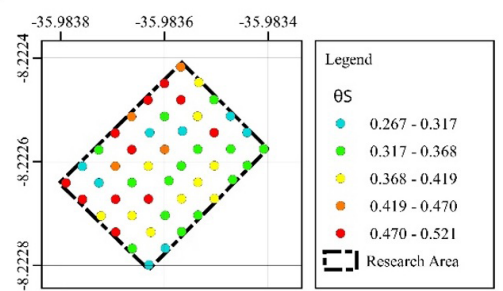

(h)

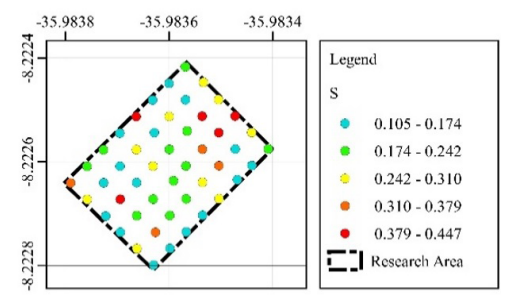

(j)

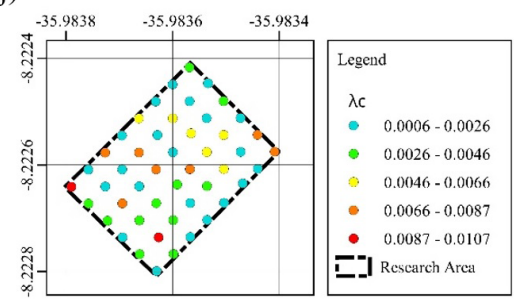

(1)

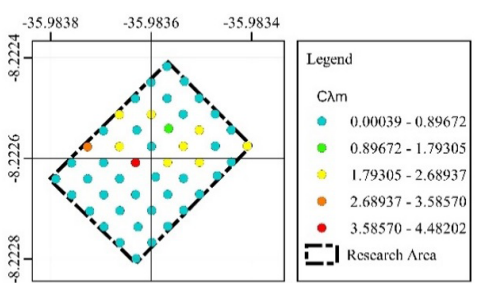

Figure 5. Spatial distribution maps of the main studied parameters, with lower indices represented by red and higher indices by blue. (a) shape parameter $m$; (b) shape parameter $n$; (c) shape parameter $\eta$; (d) soil density; (e) soil porosity, $\sigma$; (f) saturation soil water content, $\theta_{\mathrm{s}}$; (g) hydraulic conductivity, $K_{s}$; (h) sorptivity, $S$; (i) parameter $H g$; (j) scale parameter $\lambda$ c; (k) scale parameter $\lambda$ m; (l) scale parameter $C \lambda m$. 
Thus, a greater refinement in the relationship between the parameters would be obtained by associating other methods with Beerkan's methodology. This approach can estimate the hydrodynamic parameters considering their microstructure and pore arrangement.

\section{CONCLUSIONS}

The present study describes the characterization of the hydrodynamic properties (Parameters of the soil water retention curve and the conductivity curve), as well as the spatial variability of these properties in soil with native Caatinga vegetation. One used the Beerkan method and the BEST-Slope algorithm. The Beerkan method performed well in estimating hydrodynamic properties. This fact enable to reduce the scarcity of hydrodynamic information for the caatinga biome.

The results of soil's textural characterization allowed the analysis of the variability degree of the hydrodynamic properties for a homogeneous soil. This outcome is observed when considering the same textural class, and small variations in particle size distribution between the studied points.

For this soil, despite its homogeneous texture, the hydrodynamic properties related to water transfer were characterized with a medium to high variability in their indices, with evident spatial variation.

The shape parameters, $n, m$ and $\eta$ presented low variability, while $\theta \mathrm{i}$ exhibited a high variability. In regard to the hydrodynamic properties, the saturation soil water content, the saturated hydraulic conductivity and the sorptivity presented an average variability. Most of the parameters of the retention curve and the hydraulic conductivity curve were well described by the normal distribution. Particularly, the saturated hydraulic conductivity was better described by the log-normal distribution. May the necessary estimates be made from the parameters of these distributions.

These results could provide for the improvement of knowledge of hydrological processes in semiarid regions. They would contribute to improve the performance of specific hydrological models for these regions. Future works can provide an expansion of the determination of hydrodynamic properties in Caatinga areas, addressing the influence of soil ecology (Fauna, Roots, etc...) and soil structure.

\section{ACKNOWLEDGEMENTS}

The authors acknowledge the Higher Education Personnel Improvement Coordination (Coordenação de Aperfeiçoamento de Pessoal de Nível Superior - CAPES); the National Observatory of Water and Carbon Dynamics in the Caatinga Biome (Observatório Nacional da Dinâmica da Água e de Carbono no Bioma Caatinga - ONDACBC); and the Universidade Federal de Pernambuco (UFPE) for their support on the accomplishment of this research.

\section{REFERENCES}

Abaker, W. E., Berninger, F., \& Starr, M. (2018). Changes in soil hydraulic properties, soil moisture and water balance in Acacia senegal plantations of varying age in Sudan. Journal of Arid Environments, 150, 42-53. http://dx.doi.org/10.1016/j.jaridenv.2017.12.004.

Aiello, R., Bagarello, V., Barbagallo, S., Consoli, S., Di Prima, S., Giordano, G., \& Iovino, M. (2014). Anassessment of the Beerkan method for determining the hydraulic properties of a sandyloam soil. Geoderma, 235, 300-307. http://dx.doi.org/10.1016/j. geoderma.2014.07.024.

Alagna, V., Bagarello, V., Di Prima, S., Giordano, G., \& Iovino, M. (2016). Testing infiltration run effects on thee stimated water transmission properties of a sandy-loam soil. Geoderma, 267, 24-33. http://dx.doi.org/10.1016/j.geoderma.2015.12.029.

Albuquerque, U. P., Lima Araújo, E., El-Deir, A. C. A., Lima, A. L. A., Souto, A., Bezerra, B. M., Ferraz, E. M., Maria Xavier Freire, E., Sampaio, E. V., Las-Casas, F. M., Moura, G. J., Pereira, G. A., Melo, J. G., Alves Ramos, M., Rodal, M. J., Schiel, N., Lyra-Neves, R. M., Alves, R. R., Azevedo-Júnior, S. M., Telino Júnior, W. R., \& Severi, W. (2012). Caatinga revisited: ecology and conservation of an important seasonal dry forest. TheScientificWorldJournal, 2012, 205182. PMid:22919296. http://dx.doi.org/10.1100/2012/205182.

Alcoforado-Filho, F. G., Sampaio, E. V. D. S. B., \& Rodal, M. J. N. (2003). Florística e fitossociologia de um remanescente de vegetação caducifólia espinhosa arbórea em Caruaru, Pernambuco. Acta Botanica Brasílica, 17(2), 287-303. http:/ / dx.doi.org/10.1590/ S0102-33062003000200011.

Angulo-Jaramillo, R., Bagarello, V., Di Prima, S., Gosset, A., Iovino, M., \& Lassabatere, L. (2019). Beerkan Estimation of Soil Transfer parameters (BEST) across soils and scales. Journal of Hydrology, 576, 239-261. http://dx.doi.org/10.1016/j.jhydrol.2019.06.007.

Araújo, D. C. D. S., Montenegro, S. M., Montenegro, A. A. D. A., Silva Junior, V. D. P., \& Santos, S. M. D. (2018). Spatial variability of soil attributes in an experimental basin in the semi-arid region of Pernambuco, Brazil. Revista Brasileira de Engenharia Agricola e Ambiental, 22(1), 38-44. http://dx.doi.org/10.1590/1807-1929/ agriambi.v22n1p38-44.

Bagarello, V., Baiamonte, G., \& Caia, C. (2019). Variability of near-surface saturated hydraulic conductivity for the clay soils of a small Sicilian basin. Geoderma, 340, 133-145. http://dx.doi. org/10.1016/j.geoderma.2019.01.008.

Bagarello, V., Di Prima, S., Giordano, G., \& Iovino, M. (2014). A test of the Beerkan Estimation of Soil Transfer parameters (BEST) procedure. Geoderma, 221-222, 20-27. http://dx.doi. org/10.1016/j.geoderma.2014.01.017.

Barreto, A. C., Galvão, M. B., Freire, S., Freire, F. J., \& Adjunto, R.-P. (2006). Características químicas e físicas de um solo sob floresta, sistema agroflorestal e pastagem no sul da Bahia. Revista Caatinga, 19(4), 415-425.

Barros, K., Ribeiro, C. A. A. S., Marcatti, G. E., Lorenzon, A. S., Castro, N. L. M., Domingues, G. F., Carvalho, J. R., \& Santos, 
A. R. (2018). Markov chains and cellular automata to predict environments subject to desertification. Journal of Environmental Management, 225, 160-167. PMid:30081278. http://dx.doi. org/10.1016/j.jenvman.2018.07.064.

Bouarafa, S., Lassabatere, L., Lipeme-Kouyi, G., \& Angulo-Jaramillo, R. (2019). Hydrodynamic characterization of sustainable urban drainage systems (SuDS) by using Beerkan infiltration experiments. Water (Basel), 11(4), 660. http://dx.doi.org/10.3390/w11040660.

Bouslihim, Y., Rochdi, A., El Amrani Paaza, N., \& Liuzzo, L. (2019). Understanding the effects of soil data quality on SWAT model performance and hydrological processes in Tamedroust watershed (Morocco). Journal of African Earth Sciences, 160, 103616. http://dx.doi.org/10.1016/j.jafrearsci.2019.103616.

Brooks, R., \& Corey, A. (1964). Hydraulic properties of porous media (Hydrology Papers). Fort Collins: Colorado State University.

Burdine, N. (1953). Relative permeability calculations from poresize distribution data. Journal of Petroleum Technology, 5(3), 71-78. http:/ / dx.doi.org/10.2118/225-G.

Castellini, M., Di Prima, S., \& Iovino, M. (2018). Anassessment of the BEST procedure to estimate the soil water retention curve: a comparison with the evaporation method. Geoderma, 320, 82-94. http://dx.doi.org/10.1016/j.geoderma.2018.01.014.

Chagas, C., Carvalho Junior, W., Bhering, S. B., \& Calderano Filho, B. (2016). Spatial prediction of soil surface texture in a semiarid region using random forest and multiple linear regressions. Catena, 139, 232-240. http://dx.doi.org/10.1016/j.catena.2016.01.001.

Chatterjee, S., Bandyopadhyay, K. K., Pradhan, S., Singh, R., \& Datta, S. P. (2018). Effects of irrigation, crop residue mulch and nitrogen management in maize (Zea mays L.) on soil carbon pools in a sandy loam soil of Indo-gangetic plain region. Catena, 165, 207-216. http://dx.doi.org/10.1016/j.catena.2018.02.005.

Cheong, J. Y., Cho, H., Kim, S. G., Ok, S., Kim, K. Y., \& Hamm, S. Y. (2020). Relationship between in-situ hydraulic conductivity and van genuchten parameters of unsaturated fractured hornfels. The Journal of Engineering Geology, 30(2), 147-160.

Cirilo, J. (2008). Políticas públicas de recursos hídricos para o semiárido. Estudos Avançados, 22(63), 61-82. http://dx.doi.org/10.1590/ S0103-40142008000200005.

Clothier, B. E., Vogeler, I., \& Magesan, G. N. (2000). The breakdown of water repellency and solute transport through a hydrophobic soil. Journal of Hydrology, 231, 255-264. http:/ / dx.doi.org/10.1016/ S0022-1694(00)00199-2.

Coutinho, A. P., Lassabatere, L., Montenegro, S., Antonino, A. C. D., Angulo-Jaramillo, R., \& Cabral, J. J. S. P. (2016). Hydraulic characterization and hydrological behaviour of a pilot permeable pavement in an urban centre, Brazil. Hydrological Processes, 30, 42424254. http://dx.doi.org/10.1002/hyp.10985.
Di Prima, S., Lassabatère, L., Bagarello, V., Iovino, M., \& AnguloJaramillo, R. (2016). Testing a new automated single ring infiltrometer for Beerkan infiltration experiments. Geoderma, 262, 20-34. http:// dx.doi.org/10.1016/j.geoderma.2015.08.006.

Di Prima, S., Marrosu, R., Lassabatere, L., Angulo-Jaramillo, R., \& Pirastru, M. (2018). In situ characterization of preferential flow by combining plot- and point-scale infiltration experiments on a hillslope. Journal of Hydrology, 563, 633-642. http://dx.doi. org/10.1016/j.jhydrol.2018.06.033.

Fernández-Gálvez, J., Pollacco, J. A. P., Lassabatere, L., AnguloJaramillo, R., \& Carrick, S. (2019). A general Beerkan Estimation of Soil Transfer parameters method predicting hydraulic parameters of any unimodal water retention and hydraulic conductivity curves: application to the Kosugi soil hydraulic model without using particle size distribution data. Advances in Water Resources, 129, 118-130. http:/ /dx.doi.org/10.1016/j.advwatres.2019.05.005.

Gharedaghloo, B., Price, J. S., Rezanezhad, F., \& Quinton, W. L. (2018). Evaluating the hydraulic and transport properties of peat soil using pore network modeling and X-ray micro computed tomography. Journal of Hydrology, 561, 494-508. http://dx.doi. org/10.1016/j.jhydrol.2018.04.007.

Godoy, V. A., Zuquette, L. V., \& Gómez-Hernández, J. J. (2019). Spatial variability of hydraulic conductivity and solute transport parameters and their spatial correlations to soil properties. Geoderma, 339, 59-69. http://dx.doi.org/10.1016/j.geoderma.2018.12.015.

Gomes, C. D. A., Lima, J. R. D. S., Antonino, A. C. D., Soares, W. D. A., Souza, E. S., Ribeiro, A. A., Alves, E. M., Machado, C. B., \& Firmino, F. H. T. (2015). Medição e simulação dos fluxos de energia e evapotranspiração em solo cultivado com Brachiaria decumbens na Microrregião de Garanhuns - PE. Revista Brasileira de Geografia Física, 8(2), 365-376. http://dx.doi.org/10.26848/ rbgf.v8.2.p365-376.

Habibi, B., Meddi, M., Torfs, P. J. J. F., Remaoun, M., \& Van Lanen, H. A. J. (2018). Characterisation and prediction of meteorological drought using stochastic models in the semi-arid Chéliff-Zahrez basin (Algeria). Journal of Hydrology: Regional Studies, 16, 15-31. http://dx.doi.org/10.1016/j.ejrh.2018.02.005.

Han, D., Wang, G., Liu, T., Xue, B. L., Kuczera, G., \& Xu, X. (2018). Hydroclimatic response of evapotranspiration partitioning to prolonged droughts in semiarid grassland. Journal of Hydrology, 563, 766-777. http://dx.doi.org/10.1016/j.jhydrol.2018.06.048.

Haverkamp, R., Ross, P. J., Smettem, K. R. J., \& Parlange, J. Y. (1994). Three-dimensional analysis of infiltration from the disc infiltrometer: 2. Physically based infiltration equation. Water Resources Research, 30(11), 2931-2935. http://dx.doi.org/10.1029/94WR01788.

Jacomine, P. K., Cavalcanti, A. C., Burgos, N., Pessoa, S. C. P., \& da Silveira, C. O. (1973). Levantamento exploratório-reconhecimento de solos do Estado de Pernambuco (Embrapa Solos-Séries anteriores, INFOTECA-E). Recife: Divisão de Pesquisa Pedológica. 
Jha, S., \& Srivastava, R. (2018). Impact of drought on vegetation carbon storage in arid and semi-arid regions. Remote Sensing Applications: Society and Environment, 11, 22-29. http://dx.doi. org/10.1016/j.rsase.2018.04.013.

Joseph, O., Gbenga, A. E., \& Langyit, D. G. (2018). Desertification risk analysis and assessment in Northern Nigeria. Remote Sensing Applications: Society and Environment, 11, 70-82. http://dx.doi. org/10.1016/j.rsase.2018.04.012.

Keskinen, R., Räty, M., Kaseva, J., \& Hyväluoma, J. (2019). Variations in near-saturated hydraulic conductivity of arable mineral topsoils in south-western and central-eastern Finland. Agricultural and Food Science, 28(2), 70-83. http://dx.doi.org/10.23986/afsci.79329.

Kool, D., Tong, B., Tian, Z., Heitman, J. L., Sauer, T. J., \& Horton, R. (2019). Soil water retention and hydraulic conductivity dynamics follow ingtill age. Soil \& Tillage Research, 193, 95-100. http:/ /dx.doi. org/10.1016/j.still.2019.05.020.

Lafayette, F. B., Montenegro, S. M. G. L., Coutinho, A. P., Soares, W., Antonino, A. C. D., Silva, B. B., \& Rabelo, A. E. C. (2019). Experimentation and modeling of soil evaporation in underground dam in a semiarid region. Rev. Bras. Recur. Hidricos, 24, e2. http:/ / dx.doi.org/10.1590/2318-0331.2431920170167.

Lassabatère, L., Angulo-Jaramillo, R., Soria Ugalde, J. M., Cuenca, R., Braud, I., \& Haverkamp, R. (2006). Beerkan estimation of soil transfer parameters through infiltration experiments - BEST. Soil Science Society of America Journal, 70(2), 521-532. http://dx.doi. org/10.2136/sssaj2005.0026.

Li, Y., Ren, X., Hill, R., Malone, R., \& Zhao, Y. (2018). Characteristics of water infiltration in layered water-repellent soils. Pedosphere, 28(5), 775-792. http://dx.doi.org/10.1016/S1002-0160(17)60414-4.

Ma, W., Zhang, X., Zhen, Q., \& Zhang, Y. (2016). Effect of soil texture on water infiltration in semiarid reclaimed land. Water Quality Research Journal of Canada, 51(1), 33-41. http://dx.doi. org/10.2166/wqrjc.2015.025.

Marinho, F., Oehl, F., Silva, I. R., Coyne, D., Veras, J. S. N., \& Maia, L. C. (2019). High diversity of arbuscular my corrhizal fungi in natural and anthropized sites of a Brazilian tropical dry forest (Caatinga). Fungal Ecology, 40, 82-91. http://dx.doi.org/10.1016/j. funeco.2018.11.014.

Melo, R. O., Pacheco, E. P., de Castro Menezes, J., \& Cantalice, J. R. B. (2008). Susceptibilidade à compactação e correlação entre as propriedades físicas de um Neossolo sob vegetação de caatinga. Revista Caatinga, 21(5), 12-17

Minasny, B., \& McBratney, A. B. (2007). Estimating the water retention shape parameter from sand and clay content. Soil Science Society of America Journal, 71(4), 1105-1110. http://dx.doi. org/10.2136/sssaj2006.0298N.
Montenegro, A. A. A., \& Montenegro, S. M. G. L. (2006). Variabilidade espacial de classes de textura, salinidade e condutividade hidráulica de solos em planície aluvial. Revista Brasileira de Engenharia Agrícola e Ambiental, 10(1), 30-37. http://dx.doi.org/10.1590/S141543662006000100005.

Moradi, F., Moosavi, A. A., \& Moghaddam, B. K. (2016). Spatial variability of water retention parameters and saturated hydraulic conductivity in a calcareous Inceptisols (Khuzestan province of Iran) under sugarcane cropping. Archives of Agronomy and Soil Science, 62(12), 1686-1699. http://dx.doi.org/10.1080/0365034 0.2016 .1164308 .

Moret-Fernández, D., Latorre, B., Giner, M. L., Ramos, J., Alados, C. L., Castellano, C., López, M. V., Jimenez, J. J., \& Pueyo, Y. (2019). Estimation of the soil hydraulic properties from the transient infiltration curve measured on soils affected by water repellency. Catena, 178, 298-306. http://dx.doi.org/10.1016/j. catena.2019.03.031.

Mutti, P. R., Silva, L. L., Medeiros, S. S., Dubreuil, V., Mendes, K. R., Marques, T. V., Lúcio, P. S., Santos e Silva, C. M., \& Bezerra, B. G. (2019). Basin scale rainfall-evapotranspiration dynamics in a tropical semiarid environment during dry and wet years. International Journal of Applied Earth Observation and Geoinformation, 75, 29-43. http://dx.doi.org/10.1016/j.jag.2018.10.007.

Nasta, P., Assouline, S., Gates, J. B., Hopmans, J. W., \& Romano, N. (2013). prediction of unsaturated relative hydraulic conductivity from kosugi's water retention function. Procedia Environmental Sciences, 19, 609-617. http://dx.doi.org/10.1016/j.proenv.2013.06.069.

Nunes, J. A. S., Silveira, M. H. D., Silva, T. D., Nunes, P. C. M., \& Carvalho, K. D. S. (2012). Velocidade de infiltração pelo método do infiltrômetro de anéis concêntricos em latossolo vermelho de Cerrado. Enciclopédia Biosfera, 8(15), 1685-1692.

Oliveira Júnior, J. A., Souza, E. S. D., Correa, M. M., Lima, J. R. D. S., Souza, R., \& Silva Filho, L. A. D. (2014). Variabilidade espacial de propriedades hidrodinâmicas de um Neossolo Regolítico sob pastagem e caatinga. Revista Brasileira de Engenharia Agrícola e Ambiental, 18(6), 631-639. http://dx.doi.org/10.1590/S141543662014000600010.

Oliveira, M., Soares, K. M., Martins, C. C., \& Moreira, B. (2009). Caracterização morfológica e agronômica de variedades de arroz vermelho em sistema de produção agroecológica. Revista Brasileira de Agroecologia, 4(2), 2137-2139. Retrieved in 2021, April 20, from http:/ / revistas.aba-agroecologia.org.br/index.php/rbagroecologia/ article/view/7896

Paula Filho, F. J., Sampaio, A. D. S., Menezes, J. M. C., Costa, C. T. F., \& Santiago, M. O. (2019). Land uses, Nitrogen and Phosphorus estimated fluxes in a Brazilian semi-arid watershed. Journal of Arid Environments, 163, 41-49. http://dx.doi.org/10.1016/j. jaridenv.2019.01.001. 
Philip, J. R. (1987).The quasilinear analysis, the scattering analog, and other aspects of infiltration and seepage. In Y. S. Fok (Ed.), Infiltration development and application (pp. 1-27). Honolulu: Water Resources Research Center.

Picciafuoco, T., Morbidelli, R., Flammini, A., Saltalippi, C., Corradini, C., Strauss, P., \& Blöschl, G. (2019). On the estimation of spatially representative plot scale saturated hydraulic conductivity in an agricultural setting. Journal of Hydrology, 570, 106-117. http:// dx.doi.org/10.1016/j.jhydrol.2018.12.044.

Pinheiro, A., \& Teixeira, L. P. (2009). Estimativa das curvas de condutividade hidráulica e de retenção a partir de características físicas do solo. Revista de Estudos Ambientais, 11(1), 44-50. http:/ / dx.doi.org/10.7867/1983-1501.2009v11n1p44-50.

Rahmati, M., Weihermüller, L., Vanderborght, J., Pachepsky, Y. A., Mao, L., Sadeghi, S. H., Moosavi, N., Kheirfam, H., Montzka, C., Van Looy, K., Toth, B., Hazbavi, Z., Al Yamani, W., Albalasmeh, A. A., Alghzawi, M. Z., Angulo-Jaramillo, R., Antonino, A. C. D., Arampatzis, G., Armindo, R. A., Asadi, H., Bamutaze, Y., BatlleAguilar, J., Béchet, B., Becker, F., Blöschl, G., Bohne, K., Braud, I., Castellano, C., Cerdà, A., Chalhoub, M., Cichota, R., Císlerová, M., Clothier, B., Coquet, Y., Cornelis, W., Corradini, C., Coutinho, A. P., Oliveira, M. B., Macedo, J. R., Durães, M. F., Emami, H., Eskandari, I., Farajnia, A., Flammini, A., Fodor, N., Gharaibeh, M., Ghavimipanah, M. H., Ghezzehei, T. A., Giertz, S., Hatzigiannakis, E. G., Horn, R., Jiménez, J. J., Jacques, D., Keesstra, S. D., Kelishadi, H., Kiani-Harchegani, M., Kouselou, M., Kumar Jha, M., Lassabatere, L., Li, X., Liebig, M. A., Lichner, L., López, M. V., Machiwal, D., Mallants, D., Mallmann, M. S., Oliveira Marques, J. D., Marshall, M. R., Mertens, J., Meunier, F., Mohammadi, M. H., Mohanty, B. P., Pulido-Moncada, M., Montenegro, S., Morbidelli, R., MoretFernández, D., Moosavi, A. A., Mosaddeghi, M. R., Mousavi, S. B., Mozaffari, H., Nabiollahi, K., Neyshabouri, M. R., Ottoni, M. V., Ottoni Filho, T. B., Pahlavan-Rad, M. R., Panagopoulos, A., Peth, S., Peyneau, P.-E., Picciafuoco, T., Poesen, J., Pulido, M., Reinert, D. J., Reinsch, S., Rezaei, M., Roberts, F. P., Robinson, D., Rodrigo-Comino, J., Rotunno Filho, O. C., Saito, T., Suganuma, H., Saltalippi, C., Sándor, R., Schütt, B., Seeger, M., Sepehrnia, N., Sharifi Moghaddam, E., Shukla, M., Shutaro, S., Sorando, R., Stanley, A. A., Strauss, P., Su, Z., Taghizadeh-Mehrjardi, R., Taguas, E., Teixeira, W. G., Vaezi, A. R., Vafakhah, M., Vogel, T., Vogeler, I., Votrubova, J., Werner, S., Winarski, T., Yilmaz, D., Young, M. H., Zacharias, S., Zeng, Y., Zhao, Y., Zhao, H., \& Vereecken, H. (2018). Development and analysis of the Soil Water Infiltration Global database. Earth System Science Data, 10(3), 1237-1263. http:/ / dx.doi.org/10.5194/essd-10-1237-2018.

Reinert, D. J., \& Reichert, J. M. (2006). Propriedades físicas do solo. Santa Maria: Universidade Federal de Santa Maria.

Rodrigues, M. S., De Souza, C., Lima, D. D., Da Silva, S. D. P., Alves, D. C., \& Machado, N. S. (2016). Impacto do cultivo do coqueiro irrigado na qualidade física do solo na região semiárida Brasileira. Ciencia del Suelo, 34, 139-144.
Santos, C. A. G., Silva, J. F. C. B. C., \& Silva, R. M. (2012a). Caracterização hidrodinâmica dos solos da bacia experimental do riacho Guaraíra utilizando o método Beerkan. Revista Brasileira de Recursos Hidricos, 17(4), 149-160. http://dx.doi.org/10.21168/ rbrh.v17n4.p149-160.

Santos, J. C. B., Souza Júnior, V. S., Corrêa, M. M., Ribeiro, M. R., Almeida, M. D. C., \& Borges, L. E. P. (2012b). Caracterização de Neossolos Regolíticos da região semiárida do estado de Pernambuco. Revista Brasileira de Ciência do Solo, 36(3), 683-696. http://dx.doi. org/10.1590/S0100-06832012000300001.

Shwetha, P., \& Varija, K. (2015). Soil water retention curve from saturated hydraulic conductivity for sandyloam and loamysand textured soils. Aquatic Procedia, 4, 1142-1149. http://dx.doi. org/10.1016/j.aqpro.2015.02.145.

Silva, J. R. L., Montenegro, A. A. A., \& Santos, T. E. (2012). Caracterização física e hidráulica de solos em bacias experimentais do semiárido brasileiro, sob manejo conservacionista. Revista Brasileira de Engenharia Agricola e Ambiental-Agriambi, 16(1), 27-36. http://dx.doi.org/10.1590/S1415-43662012000100004.

Silva, P. F., Lima, J. R. S., Antonino, A. C. D., Souza, R., Souza, E. S., Silva, J. R. I., \& Alves, E. M. (2017). Seasonal patterns of carbon dioxide, water and energy fluxes over the Caatinga and grassland in the semi-arid region of Brazil. Journal of Arid Environments, 147, 71-82. http://dx.doi.org/10.1016/j.jaridenv.2017.09.003.

Šípek, V., Jačka, L., Seyedsadr, S., \& Trakal, L. (2019). Manifestation of spatial and temporal variability of soil hydraulic properties in the uncultivated Fluvisol and performance of hydrological model. Catena, 182, 104119. http://dx.doi.org/10.1016/j.catena.2019.104119.

Siqueira, T. M., Louzada, J. A. S., Pedrollo, O. C., Castro, N. M. R., \& de Oliveira, M. H. C. (2019). Soil physical and hydraulic properties in the Donato stream basin, RS, Brazil. Part 1: spatial variability. Revista Brasileira de Engenharia Agricola e Ambiental, 23(9), 669-674. http://dx.doi.org/10.1590/1807-1929/agriambi.v23n9p669-674.

Sousa, A. R., Albuquerque, S. F., Silva, B., Lopes, G., \& Nunes Filho, J. (2013). Caracterização e interpretação para uso agrícola de um planossolo háplico eutrófico sódico do agreste pernambucano. In Anais da $1^{a}$ Reunião Nordestina de Ciência do Solo. Areia: Programa de Pós-graduação de Ciências do Solo, Universidade Federal da Paraíba.

Souza, E. S., Antonino, A. C. D., Jaramillo, R. A., Maciel Netto, A., Montenegro, S. M. G. L., \& Silva, E. B. (2008). Variabilidade espacial dos parâmetros hidrodinâmicos de duas parcelas agrícolas no estado da Paraíba. Revista Brasileira de Ciência do Solo, 32(5), 17951804. http://dx.doi.org/10.1590/S0100-06832008000500001.

Souza, R., Souza, E., Maciel Netto, A., Almeida, A. Q., Barros Júnior, G., Silva, J. R. I., Lima, J. R. S., \& Antonino, A. C. D. (2017). Assessment of the physical quality of a Fluvisol in the Brazilian semiarid region. Geoderma Regional, 10, 175-182. http://dx.doi. org/10.1016/j.geodrs.2017.07.008. 
Souza, E. S., Antonino, A. C. D., Maciel Netto, A., Souza, R. M. S., Gondim, M. V. S., Lima, V. F., Lima, J. R. D. S., Alves, E. M., Coutinho, A. P., \& Soares, W. D. A. (2016). Comportamento hidrodinâmico de solos em cultivos de vazante no semiárido de Pernambuco. Journal of Environmental Analysis and Progress, 1(1), 52-60. http:/ /dx.doi.org/10.24221/jeap.1.1.2016.984.52-60.

Souza, E. S., Antonino, A. C., Lima, J. R. D. S., Gouveia Neto, G. D. C., Silva, J. M., \& Silva, I. D. F. (2007). Efeito do encrostamento superficial nas propriedades hidráulicas de um solo cultivado. Agrária, 2(1), 69-74. http://dx.doi.org/10.5039/agraria.v2i1a406.

United States Department of Agriculture - USDA. (1987). Soil taxonomy (754 p.). Washington D.C.: U.S. Department of Agriculture.

Ursulino, B. S., Montenegro, S. M. G. L., Coutinho, A. P., Coelho, V. H. R., Araújo, D. C. S., Gusmão, A. C. V., Santos Neto, S.., Lassabatere, L., \& Angulo-Jaramillo, R. (2019). Modelling soil water dynamics from soil hydraulic parameters estimated by an alternative method in a tropical experimental basin. Water, 11(5), 4-6. http://dx.doi.org/10.3390/w11051007.

van Genuchten, M. T. (1980). A closed-form equation for predicting the hydraulic conductivity of unsaturated soils 1 . Soil Science Society of America Journal, 44(5), 892-898. http://dx.doi.org/10.2136/sss aj1980.03615995004400050002x.

Vital, A. F. M., Santos, R. V., Lopes, J. A., \& Muraoka, T. (2015). Caracterização de um solo salinizado em área irrigada da região Semiárida. Revista Verde de Agroecologia e Desenvolvimento Sustentável, 10(4), 28. http://dx.doi.org/10.18378/rvads.v10i4.3456.

Vogelmann, E. S., Prevedello, J., \& Reichert, J. M. (2015). Origem dos compostos hidrofóbicos e seus efeitos em florestas de Pinus e Eucalyptus. Ciência Florestal, 25(4), 1067-1079. http://dx.doi. org/10.5902/1980509820670.

Vogelmann, E. S., Reichert, J. M., Prevedello, J., Awe, G. O., \& Cerdà, A. (2017). Soil moisture influences sorptivity and water repellency of topsoil aggregates in native grasslands. Geoderma, 305, 374-381. http://dx.doi.org/10.1016/j.geoderma.2017.06.024.

Warrick, A. W., \& Nielsen, D. R. (1980). Spatial variability of soil physical properties in the field. In D. Hillel (Ed.), Application of soil physics (pp. 319-344). New York: Academic Press.

White, I., \& Sully, M. J. (1987). Macroscopic and microscopic capillary leng thand time scales from field infiltration. Water Resources Research, 23(8), 1514-1522. http://dx.doi.org/10.1029/WR023i008p01514.

Yilmaz, D., Lassabatere, L., Angulo-Jaramillo, R., Deneele, D., \& Legret, M. (2010). Hydrodynamic characterization of basico xy genfurnaces lag through an adapted BEST method. Vadose Zone Journal, 9(1), 107-116. http://dx.doi.org/10.2136/vzj2009.0039.

Yost, J. L., Huang, J., \& Hartemink, A. E. (2019). Spatial-temporal analysis of soil water storage and deep drainage under irrigated potatoes in the Central Sands of Wisconsin, USA. Agricultural Water Management, 217, 226-235. http://dx.doi.org/10.1016/j. agwat.2019.02.045.

Zubelzu, S., Rodríguez-Sinobas, L., Andrés-Domenech, I., CastilloRodríguez, J. T., \& Perales-Momparler, S. (2019). Design of water reuse storage facilities in Sustainable Urban Drainage Systems from a volumetric water balance perspective. The Science of the Total Environment, 663, 133-143. PMid:30710786. http://dx.doi. org/10.1016/j.scitotenv.2019.01.342.

\section{Authors contributions}

José Martins de França Neto: Conceptualization; Methodology; Software; Validation; Formal analysis; Investigation; Data curation; Writing - original draft; Visualization.

Artur Paiva Coutinho: Conceptualization; Methodology; Software; Validation; Resources; Writing - review and editing; Supervision; Project administration; Funding acquisition.

Simone Di Prima: Conceptualization; Methodology; Writing review and editing.

Saulo de Tarso Marques Bezerra: Conceptualization; Methodology; Resources; Writing - review and editing; Supervision; Project administration.

Severino Martins dos Santos Neto: Investigation; Resources; Writing - original draft.

Ana Emília Carvalho Gusmão da Cunha Rabelo: Investigation; Data curation; Writing - original draft.

Antonio Celso Dantas Antonino: Writing - review and editing; Supervision; Project administration; Funding acquisition.

Editor-in-Chief: Adilson Pinheiro

Associated Editor: Edson Cezar Wendland 